\title{
Viability of diffuse large B-cell lymphoma cells is regulated by kynurenine 3-monooxygenase activity
}

\author{
NANAKA MORITA ${ }^{1}$, MASATO HOSHI ${ }^{2}$, TAKESHI HARA ${ }^{3,4}$, SORANOBU NINOMIYA $^{4}$, \\ TAISUKE ENOKI $^{5}$, MISAO YONEDA ${ }^{6}$, HISASHI TSURUMI ${ }^{3,4}$ and KUNIAKI SAITO ${ }^{1}$
}

\begin{abstract}
Departments of ${ }^{1}$ Disease Control and Prevention, and ${ }^{2}$ Biochemical and Analytical Science, Fujita Health University, Toyoake, Aichi 470-1192; ${ }^{3}$ First Department of Internal Medicine, Gifu University Graduate School of Medicine, Yanagido, Gifu 501-1194; ${ }^{4}$ Department of Hematology, Matsunami General Hospital, Kasamatsucho, Gifu 501-6062;

${ }^{5}$ Department of Educational Collaboration, Health and Safety Sciences, Osaka Kyoiku University, Kashiwara, Osaka 582-8285; ${ }^{6}$ Department of Pathology, Suzuka University of Medical Sciences, Suzuka, Mie 510-0293, Japan
\end{abstract}

Received June 21, 2021; Accepted September 3, 2021

DOI: $10.3892 / \mathrm{ol} .2021 .13051$

\begin{abstract}
Diffuse large B-cell lymphoma (DLBCL) is a clinically heterogeneous lymphoid malignancy that is the most common type of lymphoma in Japan. Previous studies have demonstrated that patients with DLBCL have a poor prognosis due to increased levels of indoleamine 2,3-dioxygnase and kynurenine (KYN). However, the roles of metabolites acting downstream of KYN and associated enzymes are not fully understood. The present study investigated the role of kynurenine 3-monooxygenase (KMO), which catalyzes the conversion of KYN to 3-hydroxykynurenine (3-HK), using serum samples from patients with DLBCL and human DLBCL cell lines with different KMO expression [STR-428 cells with high levels of KMO expression (KMO ${ }^{\text {high }}$ ) and KML-1 cells with low levels of KMO expression $\left(\mathrm{KMO}^{\text {low }}\right)$ ]. Serum samples from 28 patients with DLBCL and 34 healthy volunteers were used to investigate the association between prognosis and KMO activity or 3-HK levels. Furthermore, to investigate the roles of KMO and its related metabolites, STR-428 and KML-1 cell lines, and the lymph nodes of patients with DLBCL were analyzed by reverse transcription-quantitative PCR for KMO, KYNU, 3-hydroxyanthranilate-3,4-dioxygenase and quinolinate phosphoribosyltransferase, by western blotting,
\end{abstract}

Correspondence to: Dr Masato Hoshi, Department of Biochemical and Analytical Science, Fujita Health University, 1-98 Dengakugakubo, Kutsukakecho, Toyoake, Aichi 470-1192, Japan

E-mail: mhoshi@fujita-hu.ac.jp

Abbreviations: DLBCL, diffuse large B-cell lymphoma; KYN, kynurenine; 3-HK, 3-hydroxykynurenine; IDO1, indoleamine 2,3-dioxygenase 1; KMO, kynurenine 3-monooxygenase; KYNU, kynureninase; 3-HAO, 3-hydroxyanthranilate-3,4-dioxygenase; QPRT, quinolinate phosphoribosyltransferase; PS, performance status; CS, clinical stage; IPI, International Prognostic Index; R-IPI, Revised International Prognostic Index

Key words: DLBCL, KMO, NAD ${ }^{+}, 3-\mathrm{HK}, \mathrm{KYN}$ pathway and immunohistochemical or immunofluorescence staining for $\mathrm{KMO}$, and by cell viability and $\mathrm{NAD}^{+} / \mathrm{NADH}$ assays. KYN pathway metabolites in serum samples were measured by HPLC. Serum 3-HK levels were regulated independently of serum KYN levels, and increased serum 3-HK levels and KMO activity were found to be associated with worse disease progression. Notably, the addition of KMO inhibitors and $3-\mathrm{HK}$ negatively and positively regulated the viability of DLBCL cells, respectively. Furthermore, NAD ${ }^{+}$levels in $\mathrm{KMO}^{\text {high }}$ STR-428 cells were significantly higher than those in $\mathrm{KMO}^{\text {low }} \mathrm{KML}-1$ cells. These results suggested that $3-\mathrm{HK}$ generated by $\mathrm{KMO}$ activity may be involved in the regulation of DLBCL cell viability via NAD ${ }^{+}$synthesis.

\section{Introduction}

Diffuse large B-cell lymphoma (DLBCL) is a clinically heterogeneous lymphoid malignancy and the most common type of lymphoma, accounting for $35-40 \%$ of all cases in Japan (1). The current standard first-line treatment for DLBCL is a regimen that combines cyclophosphamide, doxorubicin, vincristine and prednisolone (CHOP) with an anti-CD20 monoclonal antibody, such as rituximab (R-CHOP) (2). $\mathrm{R}-\mathrm{CHOP}$ therapy is more effective than chemotherapy alone and can cure more than half of the patients with DLBCL; however, $30-40 \%$ of patients relapse or develop resistance to this treatment (3). Therefore, the establishment of novel target molecules is an important challenge in treatment-resistant and relapse cases.

It has been reported that patients with DLBCL with high expression levels of indoleamine 2,3-dioxygenase 1 (IDO1), the rate-limiting enzyme in the tryptophan pathway, which normally catalyzes tryptophan to kynurenine (KYN), and high KYN levels are associated with a poor prognosis $(4,5)$. Furthermore, high levels of IDO1 and KYN are associated with poor prognosis in other types of cancer, including acute myeloid leukemia and adult T-cell leukemia-lymphoma (6-9). Together, these findings indicate that the KYN pathway serves an important role in regulating the immune response (10-12), and thus helps cancer cells escape attacks by host immune 
cells. However, the roles of metabolites acting downstream of KYN and associated enzymes are not fully understood.

Kynurenine 3-monooxygenase (KMO), which catalyzes a rate-limiting step in the KYN pathway, converts KYN to 3-hydroxykynurenine (3-HK), ultimately leading to the production of $\mathrm{NAD}^{+}$(Fig. S1) (13). KMO is found in the mitochondria and is highly active in immune and tumor cells (14), macrophages, and various tissues, such as liver and kidney tissues $(15,16)$. KMO inhibition is considered to have beneficial effects in several cases. For example, the inhibition of KMO ameliorates neurodegenerative disorders, such as Alzheimer's disease and Huntington's disease $(17,18)$. Furthermore, the absence of KMO ameliorates symptoms in acute viral myocarditis, acute pancreatitis-induced multi-organ dysfunction syndrome and acute kidney allograft rejection (19-21). Interestingly, it has been reported that $3-\mathrm{HK}$ produced by KMO activity induces effector T-cell apoptosis in vitro, thereby regulating T-cell-dependent immune responses (22), and administration of $3-\mathrm{HK}$ as part of the treatment approach for sepsis reduces the overproduction of IL-6, which is responsible for severe endotoxemia (23). Therefore, investigating the relationship between KMO and 3-HK in DLBCL may be useful for elucidating novel therapeutic mechanisms targeting the KYN pathway.

The present study aimed to investigate the association between prognosis and KMO activity using serum samples from patients with DLBCL and human DLBCL cell lines with different levels of KMO expression. The present study revealed that $\mathrm{KMO}$-targeted therapeutic strategies may help inhibit DLBCL cell viability, and KMO activity and 3-HK levels may represent potential biomarkers in patients with lymphoid malignancies.

\section{Materials and methods}

Patients. A total of 28 patients with DLBCL (18 men and 10 women; age range, 53-93 years; mean age, 72 ) and 34 healthy adult volunteers serving as controls were included in the serum analyses. The Ethics Committees of Fujita Health University (Toyoake, Japan; approval no. HM20-268) and Gifu University (Gifu, Japan; approval no. 2018-25) approved all procedures involving human subjects, and the study was performed in accordance with the principles of the Declaration of Helsinki. All patients and healthy volunteers signed informed consent before study participation. The present study investigated healthy volunteers and 28 patients, including 7 patients for Fig. S2 (3 men and 4 women; age range, 53-90 years), who were histologically diagnosed with DLBCL according to the World Health Organization classification of hematopoietic tumors (24) between April 2008 and November 2016. Patients with DLBCL metastasis or without complete clinical information were excluded from the present study. Serum samples from patients with DLBCL were obtained before the initiation of therapy. All serum samples were separated by centrifugation $\left(1,500 \mathrm{x} \mathrm{g} ; 15 \mathrm{~min} ; 24^{\circ} \mathrm{C}\right)$ and stored at $-80^{\circ} \mathrm{C}$ until analysis. Patients $<70$ years of age were assigned to receive eight cycles of R-CHOP or rituximab, pirarubicin, cyclophosphamide, vincristine and prednisone (R-THP-COP) therapy in Gifu University Hospital (Gifu, Japan) (25-27). Patients $\geq 70$ years old received six cycles of R-CHOP or R-THP-COP therapy in
Gifu University Hospital, which is recommended for elderly patients with DLBCL (28). The clinical characteristics of patients with DLBCL at the time of diagnosis are summarized in Table I. Concerning age as a prognostic factor, a patient age cut-off of 60 was determined according to the age cut-off of the International Prognostic Index (IPI) and Revised International Prognostic Index (R-IPI) (29,30). Healthy controls, without renal dysfunction, hepatic dysfunction, pregnancy or breastfeeding, immune-mediated inflammatory disease or medications, and blood dyscrasia or anemia, were sex-matched (20 male patients; 14 female patients) and age-matched ( $<60$ years, 7 patients; $\geq 60$ years, 27 patients; age range, $47-80$ years; mean age, 66 ) to the patients with DLBCL. Blood samples from newly diagnosed patients and age- and sex-matched controls were collected at the inpatient and outpatient department (Gifu University Hospital, Gifu, Japan), respectively. All follow-up dates were based on the last entries on December 1,2020. The sample size used in the present study was determined by the number of samples collected during the study period. Therefore, due to the small sample size, statistical analysis was performed using non-parametric analysis.

Measurement of KYN pathway metabolites. 3-HK and KYN measurements were performed as previously described $(19,31)$. For KYN measurement, serum was diluted (4:1, v/v) in $10 \%$ perchloric acid. After thorough mixing, the precipitated proteins were removed by centrifugation $(7,000 \mathrm{x} \mathrm{g}$; $10 \mathrm{~min} ; 4^{\circ} \mathrm{C}$ ). A total of $50 \mu \mathrm{l}$ of the resulting supernatant was subjected to high-performance liquid chromatography (HPLC Prominence; Shimadzu) analysis. KYN was isocratically eluted from a reverse phase column [TSKgel ODS-100V; $3 \mu \mathrm{m}, 4.6 \mathrm{~mm}$ (ID) x $150 \mathrm{~mm}$ (L); Tosoh] using a mobile phase containing $10 \mathrm{mM}$ sodium acetate and $1 \%$ acetonitrile ( $\mathrm{pH}$ adjusted to $4.5 \mathrm{with}$ acetic acid) at a flow rate of $0.9 \mathrm{ml} / \mathrm{min}$. KYN was detected using an ultraviolet and visible spectrophotometric apparatus (SPD-20A; Shimadzu) (UV wavelength, $365 \mathrm{~nm})$.

For 3-HK measurement, serum was diluted $(1: 4, \mathrm{v} / \mathrm{v})$ in $10 \%$ perchloric acid. After thorough mixing, the precipitated proteins were removed by centrifugation $(7,000 \mathrm{x} \mathrm{g} ; 10 \mathrm{~min}$; $\left.4^{\circ} \mathrm{C}\right)$. A total of $20 \mu \mathrm{l}$ of the supernatant was applied to a $3-\mu \mathrm{m}$ HPLC column (HR-80; 80x4.6 mm; ESA), using a mobile phase consisting of $1.5 \%$ acetonitrile, $0.9 \%$ triethylamine, $0.59 \%$ phosphoric acid, $0.27 \mathrm{mM}$ EDTA and $8.9 \mathrm{mM}$ sodium heptane sulfonic acid, at a flow rate of $0.5 \mathrm{ml} / \mathrm{min}$. 3-HK was detected electrochemically using an ECD 300 detector (oxidation potential: $+0.55 \mathrm{~V}$; Eicom). KMO activity was calculated from the $3-\mathrm{HK} / \mathrm{KYN}$ ratio as previously described $(32,33)$. Furthermore, the present study investigated the association between changes in 3-HK levels and KMO activity and sex, age, performance status (PS), serum lactate dehydrogenase (LDH) levels, soluble interleukin-2 receptor (sIL-2R) levels, extranodal lesions, clinical stage (CS), B symptom, IPI and R-IPI to establish a link between KMO activity and characteristics of patients with DLBCL. Extranodal lesions, CS and B symptoms were assessed according to the Ann Arbor criteria, and classification was performed for all patients (34).

Cell lines and cultures. Human B-cell non-Hodgkin lymphoma cell lines (KML-1: JCRB1347) and human 
Table I. Characteristics of patients with diffuse large B-cell lymphoma.

\begin{tabular}{|c|c|}
\hline Characteristics & Cases, n (\%) \\
\hline \multicolumn{2}{|l|}{ Sex } \\
\hline Male & $18(64.2)$ \\
\hline Female & $10(35.8)$ \\
\hline \multicolumn{2}{|l|}{ Age, years } \\
\hline$<60$ & $4(14.3)$ \\
\hline$\geq 60$ & $24(85.7)$ \\
\hline \multicolumn{2}{|l|}{ PS } \\
\hline 0,1 & $23(82.1)$ \\
\hline $2-4$ & $5(17.9)$ \\
\hline \multicolumn{2}{|l|}{ LDH } \\
\hline Normal & $10(35.8)$ \\
\hline Increased & $18(64.2)$ \\
\hline \multicolumn{2}{|l|}{ sIL-2R, U/ml } \\
\hline$<2,000$ & 15 (53.6) \\
\hline$\geq 2,000$ & $13(46.4)$ \\
\hline \multicolumn{2}{|c|}{ Extranodal lesions } \\
\hline 0,1 & 17 (60.7) \\
\hline$\geq 2$ & $11(39.3)$ \\
\hline \multicolumn{2}{|l|}{ Clinical stage } \\
\hline $\mathrm{I} / \mathrm{II}$ & $5(17.9)$ \\
\hline III/IV & $23(82.1)$ \\
\hline \multicolumn{2}{|l|}{ B symptom } \\
\hline Absent & $18(64.2)$ \\
\hline Present & $10(35.8)$ \\
\hline \multicolumn{2}{|l|}{ IPI } \\
\hline $\mathrm{L} / \mathrm{LI}$ & $10(35.8)$ \\
\hline $\mathrm{HI} / \mathrm{H}$ & $18(64.2)$ \\
\hline \multicolumn{2}{|l|}{ R-IPI } \\
\hline Very good & $1(3.6)$ \\
\hline Good & $9(32.1)$ \\
\hline Poor & $18(64.2)$ \\
\hline \multicolumn{2}{|c|}{ Molecular subtypes } \\
\hline GCB & $10(35.7)$ \\
\hline $\mathrm{ABC}$ & $18(64.3)$ \\
\hline
\end{tabular}

$\mathrm{ABC}$, activated B-cell-like; GCB, germinal center B-cell-like; $\mathrm{HI} / \mathrm{H}$, high intermediate/high; IPI, International Prognostic Index; L/LI, low/low intermediate; LDH, lactate dehydrogenase; PS, performance status; R-IPI, Revised International Prognostic Index; sIL-2R, soluble interleukin-2 receptor.

DLBCL cell lines (STR-428: JCRB1384) were purchased from the Japanese Collection of Research Bioresources Cell Bank. KML-1 and STR-428 cells are positive for the surface markers CD10, CD19, CD20 and human leukocyte antigen DR (HLA-DR) $(35,36)$. Therefore, both of these cell lines are categorized as germinal center B-cell-like (GCB) types in the Hans classification (37). All tumor cells were cultured in RPMI-1640 medium (FUJIFILM Wako Pure Chemical
Corporation) supplemented with 10\% FBS (HyClone; Cytiva), $50 \mathrm{U} / \mathrm{ml}$ penicillin (Sigma-Aldrich; Merck $\mathrm{KGaA}$ ) and $50 \mu \mathrm{g} / \mathrm{ml}$ streptomycin (Sigma-Aldrich; Merck KGaA) at $37^{\circ} \mathrm{C}$ with $5 \% \mathrm{CO}_{2}$.

RNA extraction, semi-quantitative $P C R$ and reverse transcription-quantitative PCR (RT-qPCR). Total RNA was isolated from KML-1 and STR-428 cells using an Isogen RNA Isolation kit (Nippon Gene Co., Ltd.). The RNA (250 ng) was then used for first-strand synthesis of cDNA with a high-capacity cDNA reverse transcription kit (Applied Biosystems; Thermo Fisher Scientific, Inc.). Semi-quantitative RT-PCR in KML-1 and STR-428 cells was performed to detect KMO, IDO1 and $\beta$-actin cDNA using the KAPA Taq Extra HotStart Readymix PCR Kit (Nippon Gene Co., Ltd.) according to the manufacturer's protocol. The PCR products were separated on a $2 \%$ agarose gel and stained with ethidium bromide to visualize the amplified nucleic acid fragments. The mRNA expression levels of kynureninase (KYNU), 3-hydroxyanthranilate-3,4-dioxygenase (3-HAO), quinolinate phosphoribosyltransferase (QPRT) and $\beta$-actin KML-1 and STR-428 cells were quantified by qPCR on a 7900HT Fast Real-Time system (Applied Biosystems; Thermo Fisher Scientific, Inc.). KYNU-, 3-HAO-, QPRT- and $\beta$-actin-targeted reactions were performed using Sso Advanced SYBR-Green Supermix (Bio-Rad Laboratories, Inc.) according to the manufacturer's protocol (38), and data were analyzed using 7900HT software (version 2.3; Applied Biosystems; Thermo Fisher Scientific, Inc.). The PCR primers are listed in Table SI. Thermocycling conditions were as follows: Initial denaturation, $95^{\circ} \mathrm{C}$ for $30 \mathrm{sec} ; 40$ cycles of amplification (denaturation, $95^{\circ} \mathrm{C}$ for $5 \mathrm{sec}$; annealing/extension, $58^{\circ} \mathrm{C}$ for $60 \mathrm{sec}$ ). Gene expression levels were normalized to $\beta$-actin expression levels using a standard curve.

Western blotting. KML-1 and STR-428 cells were collected, $100 \mu$ l RIPA extraction buffer(FUJIFILM Wako Pure Chemical Corporation) was added per $1 \times 10^{6}$ cells, and the samples were sonicated and centrifuged at $10,000 \mathrm{x} \mathrm{g}$ for $5 \mathrm{~min}$ at $4^{\circ} \mathrm{C}$. The protein concentration in the supernatant was measured using a BCA protein assay. Subsequently, $10 \mu \mathrm{g}$ of protein was loaded onto a 10\% Mini-PROTEAN TGX gel (Bio-Rad Laboratories, Inc.), separated by SDS-PAGE and transferred to PVDF membranes. After blocking non-specific reactions with $5 \%$ skimmed milk for $1 \mathrm{~h}$ at $24^{\circ} \mathrm{C}$, the membranes were first incubated with the primary antibodies for $12 \mathrm{~h}$ at $4^{\circ} \mathrm{C}$, including anti-KMO (dilution, 1:1,000; cat. no. 10698-1-AP; ProteinTech Group, Inc.) and anti- $\beta$-actin (dilution, 1:1,000; cat. no. A5441; Sigma-Aldrich; Merck KGaA). The membrane was then incubated with horseradish peroxidase-conjugated secondary antibody for $1 \mathrm{~h}$ at $24^{\circ} \mathrm{C}$ (dilution, 1:10,000; cat. nos. 115-035-144 and 115-006-020; Jackson ImmunoResearch Laboratories, Inc.). Detection was performed using the Immunostar LD reagent (FUJIFILM Wako Pure Chemical Corporation) and a WSE-6100 Lumino Graph I instrument (ATTO Corporation).

Immunohistochemistry. The lymph node of a single patient with DLBCL was fixed in $10 \%$ formalin in PBS overnight at $24^{\circ} \mathrm{C}$ and then embedded in paraffin. Sections (thickness, 
3- $\mu \mathrm{m})$ were used for H\&E staining and KMO immunostaining. The primary antibody used was a mouse anti-KMO antibody (dilution, 1:2,000; cat. no. 60029-1-Ig; ProteinTech Group, Inc.). After deparaffinization and rehydration, sections were heated at $121^{\circ} \mathrm{C}$ for $20 \mathrm{~min}$ in Histofine antigen retrieval solution ( $\mathrm{pH}$ 9.0; Nichirei Biosciences, Inc.). The sections were soaked in $3 \%$ hydrogen peroxide in methanol for $30 \mathrm{~min}$ to eliminate endogenous peroxidase activity. After nonspecific binding was blocked for $15 \mathrm{~min}$ at $24^{\circ} \mathrm{C}$ with G-block (cat. no. GB-01; GenoStaff Co., Ltd.), the sections were incubated with or without (negative control) primary antibody overnight at $4^{\circ} \mathrm{C}$. Secondary antibody, conjugated with a peroxidase polymer (ready to use; cat. no. MP-7500; ImmPRESS Reagent anti-rabbit IgG; Vector Laboratories, Inc.) was added for $30 \mathrm{~min}$ at $24^{\circ} \mathrm{C}$ according to the manufacturer's protocol, followed by the addition of the substrate 3,3'-diaminobenzidine tetrahydrochloride (Dako; Agilent Technologies, Inc.). The sections were then counterstained with hematoxylin for $10 \mathrm{sec}$ at $24^{\circ} \mathrm{C}$.

KML-1 and STR-428 cells $\left(2 \times 10^{5}\right.$ cells $\left./ 200 \mu \mathrm{l}\right)$ were seeded on 6 -well coverslips and fixed with $4 \%$ paraformaldehyde at $24^{\circ} \mathrm{C}$ for $30 \mathrm{~min}$. Fixed cells were permeabilized in $0.1 \%$ Triton X-100 in $1 \mathrm{X}$ PBS (FUJIFILM Wako Pure Chemical Corporation) for $30 \mathrm{~min}$ at $24^{\circ} \mathrm{C}$, and blocked with $5 \%$ horse serum (Vector Laboratories, Inc.) for $1 \mathrm{~h}$ at $24^{\circ} \mathrm{C}$. Anti-KMO antibody (dilution, 1:100; cat. no. 10698-1-AP; ProteinTech Group, Inc.) was used as the primary antibody, which was hybridized with the samples for $1 \mathrm{~h}$ at $24^{\circ} \mathrm{C}$. The cells were then stained with Northern Lights anti-rabbit IgG-NL557 as the secondary antibody (dilution, 1:1,000; cat. no. NL004; R\&D Systems, Inc.) for $1 \mathrm{~h}$ at $24^{\circ} \mathrm{C}$ in the dark. Nuclei were stained with DAPI (dilution, 1:1,000; cat. no. BS04; Dojindo Molecular Technologies, Inc.) for $5 \mathrm{~min}$ at $24^{\circ} \mathrm{C}$. All immunostained slides were observed under a BX51 fluorescence microscope equipped with a DP74 digital camera (Olympus Corporation).

Cell viability assay. KML-1 and STR-428 cells were seeded in 96-well plates at a density of $1 \times 10^{4}$ cells/well, and $10 \mu 13-\mathrm{HK}$ (1 and $10 \mu \mathrm{M}$; Sigma-Aldrich; Merck KGaA) or KMO inhibitor Ro61-8048 (10 and 100 nM, Sigma-Aldrich; Merck KGaA) was added. As a control, $10 \mu \mathrm{l}$ PBS was added to the cells. After $24 \mathrm{~h}$ at $37^{\circ} \mathrm{C}$ with $5 \% \mathrm{CO}_{2}, 10 \mu \mathrm{l}$ water-soluble tetrazolium salt (WST)-1 reagent (Premix WST-1 Cell Proliferation Assay System; Takara Bio Inc.) was added and the cells were incubated for $1.5 \mathrm{~h}$ at $37^{\circ} \mathrm{C}$ with $5 \% \mathrm{CO}_{2}$. Absorbance measurements were performed on a microplate reader (main wavelength, $450 \mathrm{~nm}$; auxiliary wavelength, $620 \mathrm{~nm}$ ). The number of viable cells was quantified based on the absorbance.

Measurement of $\mathrm{NAD}^{+}$levels. $\mathrm{NAD}^{+}$levels in KML-1 and STR-428 cells were measured using the NAD ${ }^{+} / \mathrm{NADH}$ assay kit-WST (cat. no. N509; Dojindo Laboratories Inc.), which allows for the determination of intracellular amounts of total $\mathrm{NAD}^{+} / \mathrm{NADH}$ and $\mathrm{NADH}$ alone. Intracellular $\mathrm{NAD}^{+}$levels were determined by subtracting the levels of NADH from total $\mathrm{NAD}^{+} / \mathrm{NADH}$ levels.

Statistical analysis. GraphPad Prism software version 6 (GraphPad Software, Inc.) was used for all statistical analyses.
Experiments were repeated at least three times. All data are presented as the mean \pm SD. The Mann-Whitney U test (Fig. 1) and two-sided paired t-test(Fig. S2) was used to test for significant differences between two groups for patient data. Correlations between serum KYN and 3-HK levels in patients with DLBCL were analyzed using Pearson's product-moment correlation coefficient (r). Categorical variables in Tables II and III were presented as numbers, and the groups were compared using the $\chi^{2}$ or Fisher's exact test, as appropriate. For in vitro experiments, unpaired Student's t-test was used to identify significant differences between two groups. One-way analysis of variance was used for significance testing of three groups. Tukey's multiple comparison test was used for post-hoc pairwise analyses of multiple comparisons. $\mathrm{P}<0.05$ was considered to indicate a statistically significant difference.

\section{Results}

Levels of serum 3-HK and KMO activity are increased in patients with DLBCL. The levels of serum 3-HK and the ratio of $3-\mathrm{HK} / \mathrm{KYN}$, as an indicator of KMO activity $(32,33)$, were significantly higher in patients with DLBCL before treatment than in healthy controls (Fig. 1A-C). Similarly, it has been reported that the levels of KYN in patients with DLBCL are increased compared with those in healthy controls (4). However, there was no correlation between KYN and 3-HK levels in patients with DLBCL (Fig. 1D). Therefore, the levels of serum 3-HK in patients with DLBCL were altered independently of KYN levels.

Serum 3-HK levels and KMO activity in patients with DLBCL are associated with disease progression. To investigate associations between the serum 3-HK levels or KMO activity and clinical characteristics of patients with DLBCL, patients with DLBCL were classified into low or high groups based on the median serum 3-HK levels (cut-off value, $21.9 \mathrm{nM}$ ) or $\mathrm{KMO}$ activity (cut-off value, 9.2). No significant associations between 3-HK levels or KMO activity and sex, age, PS, LDH, sIL-2R, molecular subtypes, extranodal lesions or B symptoms were observed. Importantly, 3-HK levels were significantly associated with CS, IPI and R-IPI. KMO activity was significantly associated with CS, but not IPI and R-IPI (Tables II and III). Furthermore, the levels of serum 3-HK and KMO activity in patients after treatment tended to be decreased compared with those measured before treatment (Fig. S2). These results suggested that serum 3-HK levels and KMO activity may reflect tumor progression.

KMO-mediated $\mathrm{NAD}^{+}$synthesis regulates $\mathrm{DLBCL}$ cell viability. To confirm KMO expression and its roles in DLBCL cells, the present study investigated KMO expression in KML-1 and STR-428 cells, and lymph nodes of patients with DLBCL. KML-1 (B-cell non-Hodgkin lymphoma) and STR-428 (DLBCL) cell lines exhibited a difference in KMO expression despite being derived from patients with the same disease and pathological classification (GCB type). Notably, STR-428 cells exhibited high levels of KMO expression $\left(\mathrm{KMO}^{\text {high }}\right)$, whereas KML-1 cells exhibited low levels of KMO expression (KMO low; Fig. 2A-C). Both cell lines were negative for IDO1 mRNA using RT-PCR (data not shown). High levels 
Table II. Associations between the levels of serum 3-HK and clinical characteristics of patients with diffuse large B-cell lymphoma.

\begin{tabular}{|c|c|c|c|}
\hline \multirow[b]{2}{*}{ Characteristics } & \multicolumn{2}{|c|}{ 3-HK levels, nM } & \multirow[b]{2}{*}{ P-value } \\
\hline & $<21.9, \mathrm{n}$ & $\geq 21.9, \mathrm{n}$ & \\
\hline \multicolumn{4}{|l|}{ Sex } \\
\hline Male & 7 & 11 & 0.6979 \\
\hline Female & 5 & 5 & \\
\hline \multicolumn{4}{|l|}{ Age, years } \\
\hline$<60$ & 3 & 1 & 0.2850 \\
\hline$\geq 60$ & 9 & 15 & \\
\hline \multicolumn{4}{|l|}{ PS } \\
\hline 0,1 & 10 & 13 & $>0.9999$ \\
\hline $2-4$ & 2 & 3 & \\
\hline \multicolumn{4}{|l|}{$\mathrm{LDH}$} \\
\hline Normal & 6 & 4 & 0.2425 \\
\hline Increased & 6 & 12 & \\
\hline \multicolumn{4}{|l|}{ sIL-2R, U/ml } \\
\hline$<2,000$ & 8 & 7 & 0.4120 \\
\hline$\geq 2,000$ & 4 & 9 & \\
\hline \multicolumn{4}{|l|}{ Extranodal lesions } \\
\hline 0,1 & 9 & 8 & 0.2530 \\
\hline$\geq 2$ & 3 & 8 & \\
\hline \multicolumn{4}{|l|}{ Clinical stage } \\
\hline $\mathrm{I} / \mathrm{II}$ & 5 & 0 & 0.0081 \\
\hline III/IV & 7 & 16 & \\
\hline \multicolumn{4}{|l|}{ B symptom } \\
\hline Absent & 10 & 8 & 0.1144 \\
\hline Present & 2 & 8 & \\
\hline \multicolumn{4}{|l|}{ IPI } \\
\hline $\mathrm{L} / \mathrm{LI}$ & 7 & 3 & 0.0497 \\
\hline $\mathrm{HI} / \mathrm{H}$ & 5 & 13 & \\
\hline \multicolumn{4}{|l|}{ R-IPI } \\
\hline Very good/good & 7 & 3 & 0.0497 \\
\hline Poor & 5 & 13 & \\
\hline \multicolumn{4}{|c|}{ Molecular subtypes } \\
\hline GCB & 4 & 6 & $>0.9999$ \\
\hline $\mathrm{ABC}$ & 8 & 10 & \\
\hline \multicolumn{4}{|c|}{$\begin{array}{l}\text { sIL-2R was analyzed using the } \chi^{2} \text { test, and other clinicopatho- } \\
\text { logical characteristics were analyzed using Fisher's exact test. 3-HK, } \\
\text { 3-hydroxykynurenine; ABC, activated B-cell-like; GCB, germinal } \\
\text { center B-cell-like; HI/H, high intermediate/high; IPI, International } \\
\text { Prognostic Index; L/LI, low/low intermediate; LDH, lactate dehy- } \\
\text { drogenase; PS, performance status; R-IPI, Revised International } \\
\text { Prognostic Index; sIL-2R, soluble interleukin-2 receptor. }\end{array}$} \\
\hline
\end{tabular}

of KMO expression were also observed in the lymph nodes of patients with DLBCL compared with those in the negative controls (Fig. 2D).

To investigate the role of KMO expression in DLBCL cells, the present study examined cell viability upon KMO
Table III. Associations between the levels of serum KMO activity and clinical characteristics of patients with diffuse large B-cell lymphoma.

\begin{tabular}{|c|c|c|c|}
\hline \multirow[b]{2}{*}{ Characteristics } & \multicolumn{2}{|c|}{$\begin{array}{c}\text { KMO activity } \\
\text { (3-HK/KYN ratio) }\end{array}$} & \multirow[b]{2}{*}{ P-value } \\
\hline & $<9.2$ & $\geq 9.2$ & \\
\hline \multicolumn{4}{|l|}{ Sex } \\
\hline Male & 9 & 9 & \multirow[t]{2}{*}{$>0.9999$} \\
\hline Female & 5 & 5 & \\
\hline \multicolumn{4}{|l|}{ Age, years } \\
\hline$<60$ & 3 & 1 & \multirow[t]{2}{*}{0.5956} \\
\hline$\geq 60$ & 11 & 13 & \\
\hline \multicolumn{4}{|l|}{ PS } \\
\hline 0,1 & 11 & 12 & \multirow[t]{2}{*}{$>0.9999$} \\
\hline $2-4$ & 3 & 2 & \\
\hline \multicolumn{4}{|l|}{ LDH } \\
\hline Normal & 6 & 4 & \multirow[t]{2}{*}{0.6946} \\
\hline Increased & 8 & 10 & \\
\hline \multicolumn{4}{|l|}{ sIL-2R, U/ml } \\
\hline$<2,000$ & 8 & 7 & \multirow[t]{2}{*}{$>0.9999$} \\
\hline$\geq 2,000$ & 6 & 7 & \\
\hline \multicolumn{4}{|l|}{ Extranodal lesions } \\
\hline 0,1 & 11 & 6 & \multirow[t]{2}{*}{0.1217} \\
\hline$\geq 2$ & 3 & 8 & \\
\hline \multicolumn{4}{|l|}{ Clinical stage } \\
\hline $\mathrm{I} / \mathrm{II}$ & 5 & 0 & \multirow[t]{2}{*}{0.0407} \\
\hline III/IV & 9 & 14 & \\
\hline \multicolumn{4}{|l|}{ B symptom } \\
\hline Absent & 11 & 7 & \multirow[t]{2}{*}{0.2365} \\
\hline Present & 3 & 7 & \\
\hline \multicolumn{4}{|l|}{ IPI } \\
\hline $\mathrm{L} / \mathrm{LI}$ & 7 & 3 & \multirow[t]{2}{*}{0.2365} \\
\hline $\mathrm{HI} / \mathrm{H}$ & 7 & 11 & \\
\hline \multicolumn{4}{|l|}{ R-IPI } \\
\hline Very good/good & 7 & 3 & \multirow[t]{2}{*}{0.2365} \\
\hline Poor & 7 & 11 & \\
\hline \multicolumn{4}{|l|}{ Molecular subtypes } \\
\hline GCB & 5 & 5 & \multirow[t]{2}{*}{$>0.9999$} \\
\hline $\mathrm{ABC}$ & 9 & 9 & \\
\hline
\end{tabular}

sIL-2R and extranodal lesions were analyzed using the $\chi^{2}$ test, and other clinicopathological characteristics were analyzed using Fisher's exact test. 3-HK, 3-hydroxykynurenine; ABC, activated B-cell-like; GCB, germinal center B-cell-like; HI/H, high intermediate/high; IPI, International Prognostic Index; KMO, kynurenine 3-monooxygenase; KYN, kynurenine; L/LI, low/low intermediate; LDH, lactate dehydrogenase; PS, performance status; R-IPI, Revised International Prognostic Index; sIL-2R, soluble interleukin-2 receptor.

inhibition or 3-HK addition. Spontaneous cell viability of $\mathrm{KMO}^{\text {high }}$ STR-428 cells, which have the ability to produce higher 3-HK levels, was much higher than that of $\mathrm{KMO}^{\text {low }}$ 
A
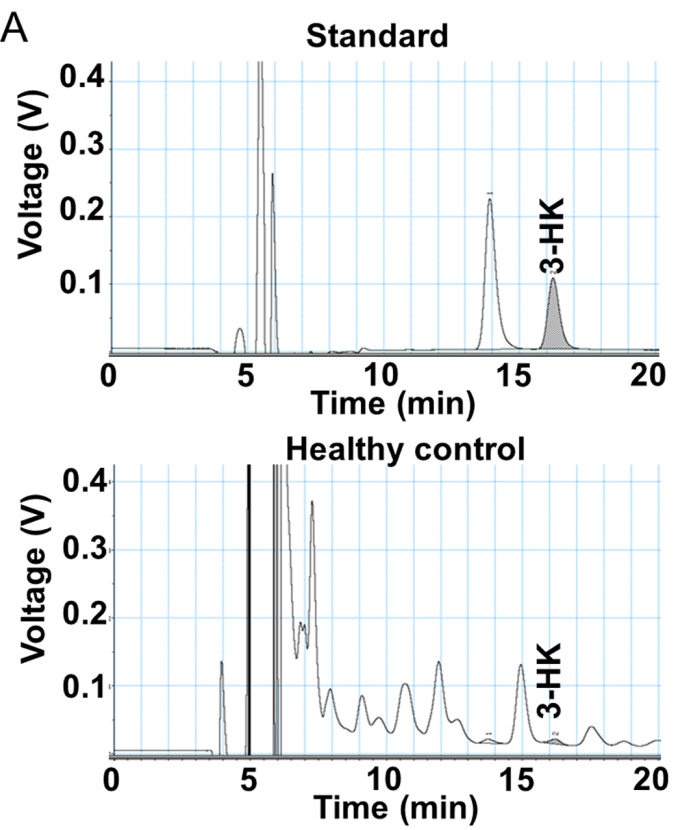

Patient with DLBCL (Before treatment)
B
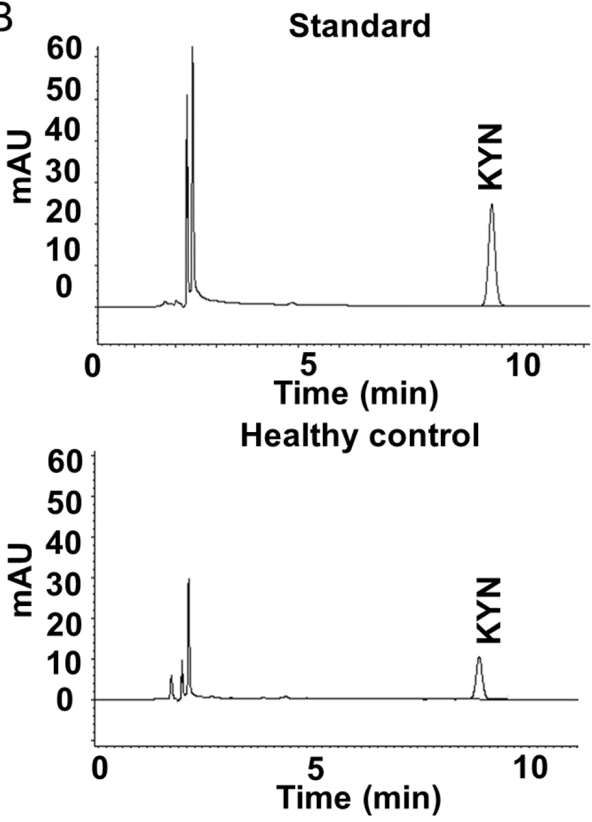
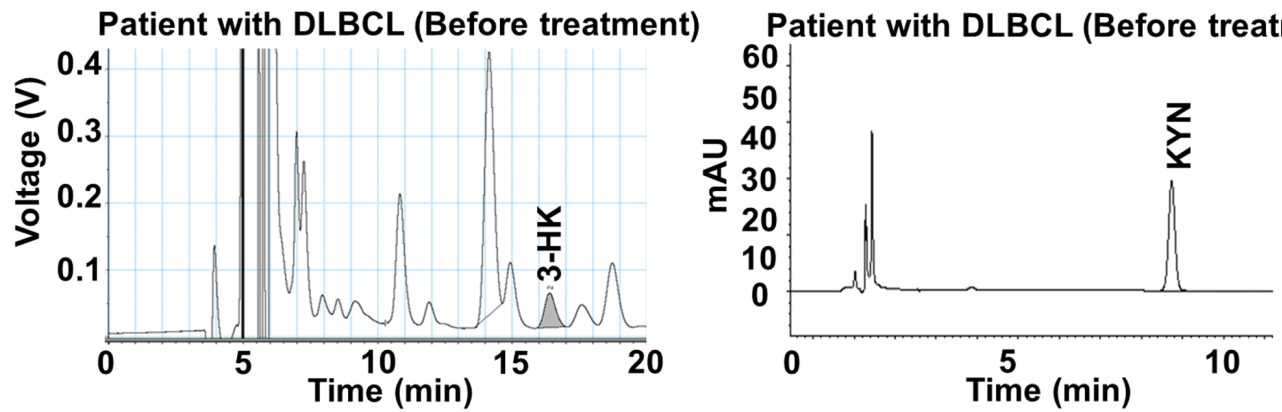

C
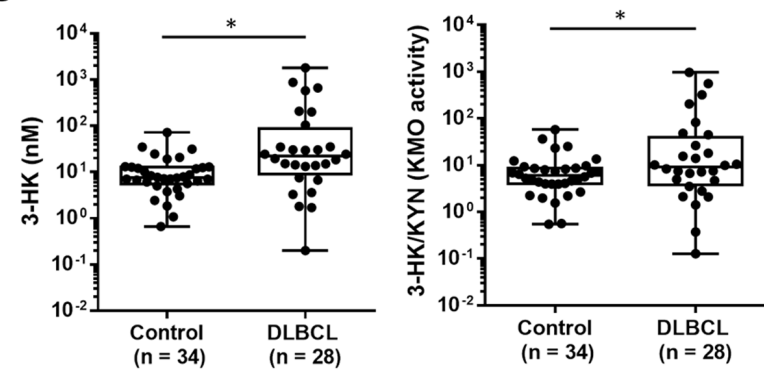

D

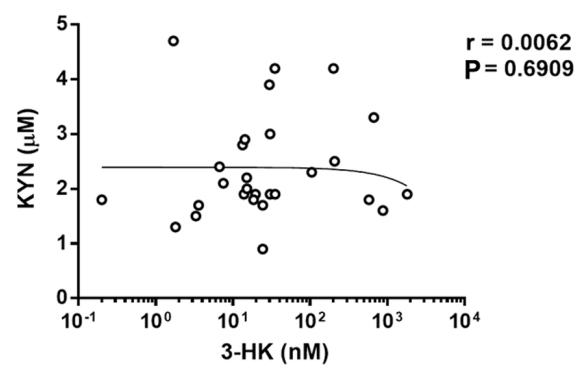

Figure 1. 3-HK levels in patients with DLBCL are regulated by KMO activity. Representative HPLC chromatograms of (A) 3-HK and (B) KYN in the sera Standard substance (top), healthy control (middle) and patient with DLBCL (bottom). (C) 3-HK levels (left) and 3-HK/KYN ratio (KMO activity; right) in the sera of patients and healthy controls as measured by HPLC. (D) Correlation of serum KYN and 3-HK levels in patients with DLBCL. Data are presented as the mean $\pm \mathrm{SD} .{ }^{*} \mathrm{P}<0.05$ (Mann-Whitney U test). 3-HK, 3-hydroxykynurenine; DLBCL, diffuse large B-cell lymphoma; HPLC, high-performance liquid chromatography; KMO, kynurenine 3-monooxygenase; KYN, kynurenine.

KML-1 cells, which have the ability to produce lower 3-HK levels (untreated ' 0 ' in Fig. 2). Notably, although the addition of $3-\mathrm{HK}$ to $\mathrm{KMO}^{\text {low }} \mathrm{KML}-1$ cells significantly improved cell viability, $\mathrm{KMO}^{\text {high }}$ STR-428 cells were not affected (Fig. 2E). By contrast, KMO inhibition in $\mathrm{KMO}^{\text {high }}$ STR-428 cells using Ro61-8048 reduced cell viability, but $\mathrm{KMO}^{\text {low }}$ KML-1 cells were not affected (Fig. 2F). These results suggested that the viability of DLBCL cells may be regulated by the production of 3-HK through KMO activity.

$\mathrm{NAD}^{+}$is an essential coenzyme involved in cell redox reactions and is required for cell proliferation as a substrate for $\mathrm{NAD}^{+}$-dependent enzymes (39). Therefore, it was hypothesized that the difference in viability of these DLBCL cell lines resulted from an increase in the levels of $\mathrm{NAD}^{+}$, the final product of the KYN pathway. To test this hypothesis, the present study investigated the mRNA expression levels of KYNU, 3-HAO and QPRT, which encode metabolic enzymes downstream of KMO. The mRNA expression levels of KYNU and QPRT were significantly higher in KML-1 cells than in STR-428 cells. Furthermore, the mRNA expression levels of 3-HAO were significantly lower in KML-1 cells than in STR-428 cells (Fig. 2G). Notably, NAD ${ }^{+}$levels in $\mathrm{KMO}^{\text {high }}$ STR-428 cells were significantly increased compared with those in $\mathrm{KMO}^{\text {low }} \mathrm{KML}-1$ cells (Fig. $2 \mathrm{H}$ ). 

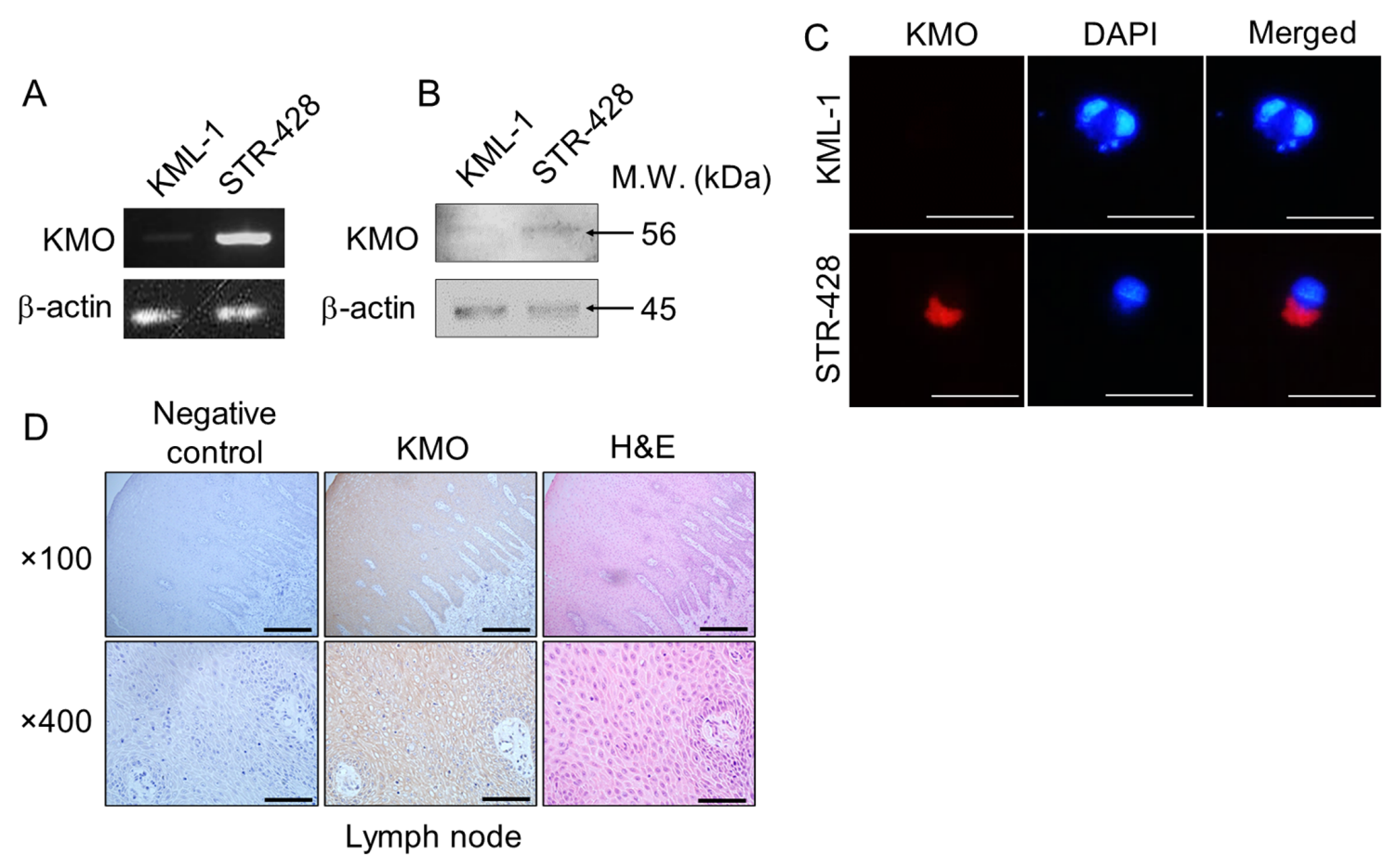

E
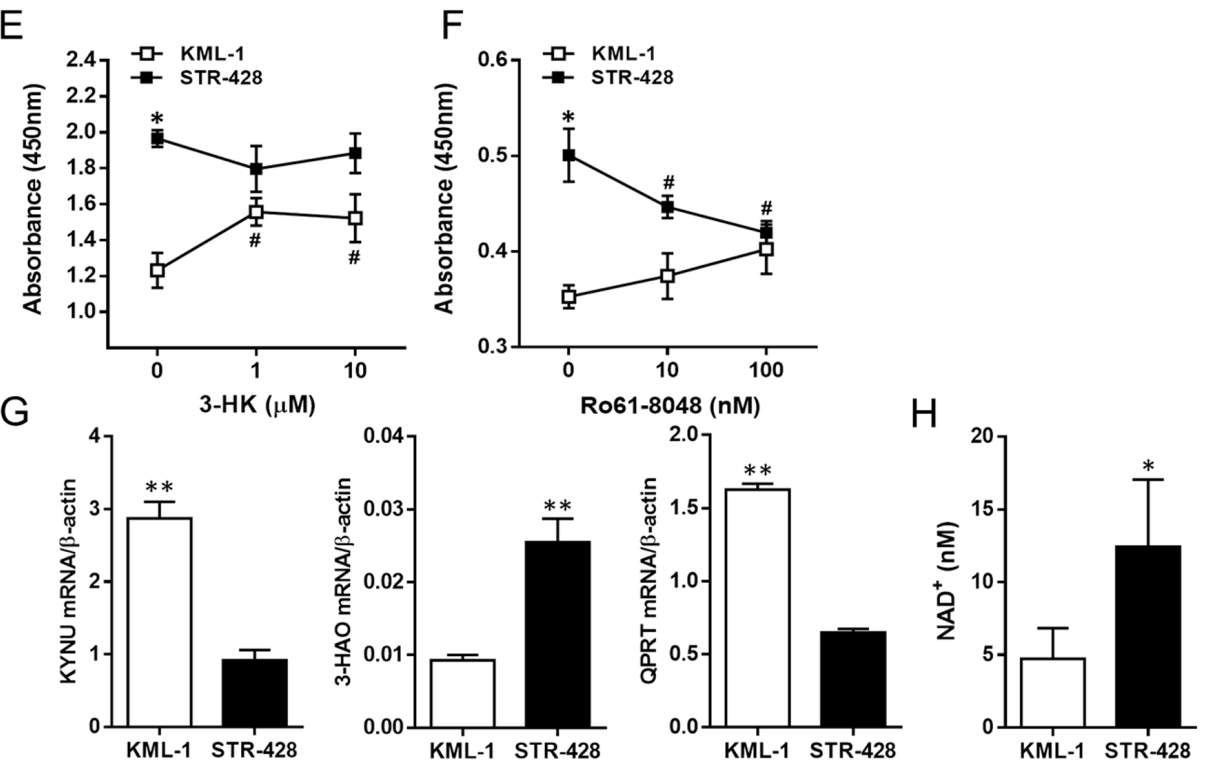

Figure 2. 3-HK produced by KMO activity increases viability of DLBCL cells. (A) mRNA expression levels of KMO in each DLBCL cell line determined by reverse transcription PCR. (B) Protein expression levels of KMO in each DLBCL cell line determined by western blotting. (C) Immunofluorescence staining of KMO in KML-1 and STR-428 cells. The cytoplasmic staining of KMO is shown in red and DAPI-stained nuclei are shown in blue. Scale bar, $20 \mu \mathrm{m}$. (D) Immunohistochemical staining of KMO in the lymph nodes of patients with DLBCL [magnification, x100 (upper panels) or x400 (lower panels)]. Negative control (left), KMO (middle) and H\&E staining (right). Scale bar, $200 \mu \mathrm{m}$ (upper panels) or $50 \mu \mathrm{m}$ (lower panels). (E) Viability of each DLBCL cell line after addition of 3-HK. (F) Viability of each DLBCL cell line after the addition of Ro61-8048. (G) mRNA expression levels of KYNU, 3-HAO and QPRT in each DLBCL cell line measured by quantitative RT-PCR. (H) NAD levels in the culture supernatants of DLBCL cell lines were measured using a NAD ${ }^{+}$assay. Data are presented as the mean $\pm \mathrm{SD}\left(\mathrm{n}=3\right.$ per group). ${ }^{*} \mathrm{P}<0.05,{ }^{* *} \mathrm{P}<0.001$ for KML-1 compared with STR-428 (unpaired Student's t-test). ${ }^{*} \mathrm{P}<0.05$ compared with the control $(0 \mu \mathrm{M}$ for 3-HK and $0 \mathrm{nM}$ for Ro61-8048) (one-way ANOVA followed by Tukey's multiple comparison test). 3-HAO, 3-hydroxyanthranilate-3,4-dioxygenase; 3-HK, 3-hydroxykynurenine; DLBCL, diffuse large B-cell lymphoma; KMO, kynurenine 3-monooxygenase; KYNU, kynureninase; QPRT, quinolinate phosphoribosyl transferase.

\section{Discussion}

The present study demonstrated that serum 3-HK levels varied independently of KYN levels in patients with DLBCL, and increased serum 3-HK levels and KMO activity served as indicators of disease progression. Furthermore, the addition of KMO inhibitors or 3-HK could regulate the viability of DLBCL cells in vitro.
Previous studies have suggested that increased KYN levels in IDO ${ }^{\text {high }}$-expressing DLBCL cells were associated with poor prognosis compared with that in IDO $^{\text {low }}$-expressing DLBCL cells $(4,5)$. Therefore, it was hypothesized that KYN produced by DLBCL cells affects the surrounding immune cells, resulting in immune escape. For example, KYN inhibits T cell proliferation, promotes $\mathrm{T}$ cell apoptosis, and induces the differentiation of naive $\mathrm{T}$ cells into regulatory $\mathrm{T}$ cells by activating 
the aryl hydrocarbon receptor $(11,12)$. In the present study, despite the fact that the serum 3-HK levels in patients with DLBCL varied independently of KYN levels, increased serum 3-HK levels and KMO activity in patients with DLBCL were significantly associated with worse CS, IPI and R-IPI grades. Since KMO is an intracellular enzyme (13), 3-HK and KYN levels in the serum were measured instead to indirectly determine KMO activity. In this context, some metabolites produced in the cytoplasm can be secreted and diffuse rapidly into various tissues via blood circulation (40). The present results showed that KMO activity could be determined based on the levels of 3-HK and KYN in the sera. It has been reported that local concentrations within tumors are likely to be far higher than those in serum $(5,41)$. Based on the present results and information, the 3-HK levels in the serum were associated with tumorigenesis. Therefore, these results suggested that there is not merely an immune escape mechanism based on increased KYN in disease progression of DLBCL, such as T cell suppression, but also another mechanism through KMO activity. The levels of $3-\mathrm{HK}$ and $\mathrm{KMO}$ activity were low in stage I/II, and lower KMO activity and 3-HK levels were not associated with $\mathrm{T}$ cell suppression. Therefore, KMO-derived 3-HK in DLBCL cells may affect disease progression and elucidating the role of 3-HK produced through KMO activation may provide a novel target for DLBCL diagnosis and treatment.

In the present study, the differences in 3-HK levels between healthy volunteers and patients were small but significant. In this context, it was considered that patients with DLBCL are divided into at least three types: $\mathrm{KMO}^{\text {low }}$-predominant type, $\mathrm{KMO}^{\text {high }}$-predominant type and both. Therefore, it is possible that patients with DLBCL with lower 3-HK have the $\mathrm{KMO}^{\text {low }}$ type. Therefore, $\mathrm{KMO}^{\text {low }} \mathrm{KML}-1$ and $\mathrm{KMO}^{\text {high }}$ STR-428 cells were used to evaluate the roles of $3-\mathrm{HK}$ and $\mathrm{KMO}$ in DLBCL. Interestingly, the addition of KMO inhibitor negatively regulated the viability of the $\mathrm{KMO}^{\text {high }}$ STR-428 cells, whereas the addition of 3-HK positively regulated the viability of the $\mathrm{KMO}^{\text {low }} \mathrm{KML}-1$ cells. However, although the addition of 3-HK in KML-1 cells resulted in changes, these were not dose-dependent. 3-HK is known as a free radical generator (42). Therefore, a high dose of 3-HK may cause cell death in KML-1 cells. Future studies on KMO-overexpressing cells are required to further investigate the role of $3-\mathrm{HK}$ in cell proliferation. Furthermore, the KMO inhibitor Ro61-8048 acted only on $\mathrm{KMO}^{\text {high }}$ STR-428 cells and inhibited their viability. However, $\mathrm{KMO}^{\text {low }} \mathrm{KML}-1$ cells were able to escape the inhibitory effect of Ro61-8048 to maintain viability. Therefore, although the de novo synthesis pathway of $\mathrm{NAD}^{+}$via $\mathrm{KMO}$ was inhibited, the nicotinic acid contained in the medium allowed the $\mathrm{KMO}^{\text {low }}$ KML cells to survive. By contrast, it was hypothesized that the de novo synthesis pathway was more activated in $\mathrm{KMO}^{\text {high }}$ STR cells than in $\mathrm{KMO}^{\text {low }} \mathrm{KML}$ cells, which accentuated the effect of KMO inhibition. NAD ${ }^{+}$regulates numerous metabolic pathways, including transcription, DNA repair, cell cycle and apoptosis (43), and is essential for tumor cell proliferation (39). Therefore, DLBCL cells may also require $\mathrm{NAD}^{+}$for their proliferation. NAD ${ }^{+}$-dependent enzymes, such as GAPDH and the sirtuin family of ADP-ribosyltransferases, have been reported to be involved in the proliferation of DLBCL cells $(44,45)$. One pathway for $\mathrm{NAD}^{+}$synthesis is the KYN pathway, of which KMO is the rate-limiting enzyme (13). The addition of
3-HK increases $\mathrm{NAD}^{+}$levels in human primary astrocytes and neurons (46). By contrast, the addition of KMO inhibitors results in decreased NAD ${ }^{+}$levels in HeLa cells (47). The present study revealed that $\mathrm{KMO}$ expression positively regulated $\mathrm{NAD}^{+}$levels in DLBCL cells in vitro. Although the verification of the in vitro results in primary cells as a potential limitation of the present study requires further investigation, the present study provided insights into the biological function of KMO in DLBCL cells. The present results revealed that the mRNA levels of KMO and 3-HAO were increased in STR-428 cells but not in KML-1 cells. Therefore, it was hypothesized that KMO and 3-HAO are involved in regulating NAD ${ }^{+}$levels, at least in DLBCL cells. By contrast, KYNU and QPRT, which were highly expressed in KML-1 cells, did not affect NAD ${ }^{+}$levels. In this respect, although it was speculated that the lowered substrate levels of KYNU and QPRT were associated with low KMO expression, further studies are required to clarify these results.

In conclusion, patients with DLBCL with advanced CS, IPI and R-IPI had increased levels of 3-HK. An in vitro study with human DLBCL cell lines revealed constitutively different KMO expression (KMO ${ }^{\text {low }}$ KML-1 cells and $\mathrm{KMO}^{\text {high }}$ STR-428 cells), suggesting that differential expression affects $\mathrm{NAD}^{+}$synthesis levels. Furthermore, the addition of KMO inhibitors reduced the viability of $\mathrm{KMO}^{\text {high }}$ STR-428 cells. Therefore, high KMO activity in patients with DLBCL is associated with advanced tumor growth and CS. Although treatments targeting the KYN pathway, such as IDO1, alone have not been sufficiently effective $(48,49)$, the present results suggested that KMO may be a potential target for novel therapeutic strategies. Notably, although patients with GCB-type DLBCL are generally known to have an improved prognosis compared with those with the activated B cell type (50), the present study demonstrated that the prognosis and response to treatment may differ depending on the expression levels of KMO in patients with the GCB type. However, further studies evaluating more cases are required to clarify the association between KMO activity and prognosis.

\section{Acknowledgements}

The authors would like to thank Dr Hiroyuki Tezuka (Department of CellularFunction Analysis, Research Promotion and Support Headquarters, Fujita Health University, Toyoake, Japan) and Dr Naoe Goto (Department of Hematology, Fujita Health University Hospital, Toyoake, Japan) for their advice on this experiment.

\section{Funding}

The present study was supported by a Fujita Health University Grant (grant no. MH-2020).

\section{Availability of data and materials}

The datasets used and/or analyzed during the current study are available from the corresponding author on reasonable request.

\section{Authors' contributions}

$\mathrm{MH}$ and $\mathrm{KS}$ planned the experiments. NM, MH, SN and TH performed the experiments. NM, MH and TH were respon- 
sible for data integrity and data analysis. NM, MH, SN, TE, MY, TH, HT and KS discussed the results. NM and MH wrote the manuscript. MH, TH, TE, MY, HT and KS conducted the research. NM and $\mathrm{MH}$ confirm the authenticity of all the raw data. KS had primary responsibility for the final content. All authors read and approved the final manuscript.

\section{Ethics approval and consent to participate}

The present study was approved by the Ethics Review Committee of Fujita Health University (Toyoake, Japan; approval no. HM19-182) and Gifu University (Gifu, Japan; approval no. 2018-25), and written informed consent was provided by all patients and healthy controls prior to the study start.

\section{Patient consent for publication}

Not applicable.

\section{Competing interests}

The authors declare that they have no competing interests.

\section{References}

1. No authors listed: The world health organization classification of malignant lymphomas in japan: Incidence of recently recognized entities. Lymphoma Study Group of Japanese Pathologist. Patho Int 50: 696-702, 2000.

2. Flowers CR, Sinha R and Vose JM: Improving outcomes for patients with diffuse large B-cell lymphoma. CA Cancer J Clin 60: 393-408, 2010.

3. Feugier P, Van Hoof A, Sebban C, Solal-Celigny P, Bouabdallah R, Fermé C, Christian B, Lepage E, Tilly H, Morschhauser F, et al: Long-term results of the R-CHOP study in the treatment of elderly patients with diffuse large B-cell lymphoma: A study by the Groupe d'Etude des Lymphomes de l'Adulte. J Clin Oncol 23: 4117-4126, 2005

4. Yoshikawa T, Hara T, Tsurumi H, Goto N, Hoshi M, Kitagawa J, Kanemura N, Kasahara S, Ito H, Takemura M, et al: Serum concentration of L-kynurenine predicts the clinical outcome of patients with diffuse large B-cell lymphoma treated with R-CHOP. Eur J Haematol 84: 304-309, 2010.

5. Ninomiya S, Hara T, Tsurumi H, Goto N, Saito K, Seishima M, Takami $\mathrm{T}$ and Moriwaki H: Indoleamine 2,3-dioxygenase expression and serum kynurenine concentrations in patients with diffuse large B-cell lymphoma. Leuk Lymphoma 53: 1143-1145, 2012.

6. Corm S, Berthon C, Imbenotte M, Biggio V, Lhermitte M, Dupont C, Briche I and Quesnel B: Indoleamine 2,3-dioxygenase activity of acute myeloid leukemia cells can be measured from patients' sera by HPLC and is inducible by IFN-gamma. Leuk Res 33: 490-494, 2009.

7. Masaki A, Ishida T, Maeda Y, Suzuki S, Ito A, Takino H, Ogura H, Totani H, Yoshida T, Kinoshita S, et al: Prognostic significance of tryptophan catabolism in adult T-cell leukemia/lymphoma. Clin Cancer Res 21: 2830-2839, 2015

8. Moretti S, Menicali E, Voce P, Morelli S, Cantarelli S, Sponziello M, Colella R, Fallarino F, Orabona C, Alunno A, et al: Indoleamine 2,3-dioxygenase 1 (IDO1) is up-regulated in thyroid carcinoma and drives the development of an immunosuppressant tumor microenvironment. J Clin Endocrinol Metab 99: E832-E840, 2014.

9. Hoshi M, Ito H, Fujigaki H, Takemura M, Takahashi T, Tomita E, Ohyama M, Tanaka R, Saito K and Seishima M: Indoleamine 2,3-dioxygenase is highly expressed in human adult T-cell leukemia/ lymphoma and chemotherapy changes tryptophan catabolism in serum and reduced activity. Leuk Res 33: 39-45, 2009.

10. Munn DH, Shafizadeh E, Attwood JT, Bondarev I, Pashine A and Mellor AL: Inhibition of T cell proliferation by macrophage tryptophan catabolism. J Exp Med 189: 1363-1372, 1999.
11. Fallarino F, Grohmann U, Vacca C, Orabona C, Spreca A, Fioretti MC and Puccetti P: T cell apoptosis by kynurenines. Adv Exp Med Biol 527: 183-190, 2003.

12. Mezrich JD, Fechner JH, Zhang X, Johnson BP, Burlingham WJ and Bradfield CA: An interaction between kynurenine and the aryl hydrocarbon receptor can generate regulatory $\mathrm{T}$ cells. J Immunol 185: 3190-3198, 2010.

13. Kolodziej LR, Paleolog EM and Williams RO: Kynurenine metabolism in health and disease. Amino Acids 41: 1173-1183, 2011.

14. Chiu YH, Lei HJ, Huang KC, Chiang YL and Lin CS: Overexpression of kynurenine 3-monooxygenase correlates with cancer malignancy and predicts poor prognosis in canine mammary gland tumors. J Oncol 2019: 6201764, 2019.

15. De Castro FT, Brown RR and Price JM: The intermediary metabolism of tryptophan by cat and rat tissue preparations. J Biol Chem 228: 777-784, 1957.

16. Heyes MP, Chen CY, Major EO and Saito K: Different kynurenine pathway enzymes limit quinolinic acid formation by various human cell types. Biochem J 326: 351-356, 1997.

17. Thevandavakkam MA, Schwarcz R, Muchowski PJ and Giorgini F: Targeting kynurenine 3-monooxygenase (KMO): Implications for therapy in Huntington's disease. CNS Neurol Disord Drug Targets 9: 791-800, 2010.

18. Zwilling D, Huang SY, Sathyasaikumar KV, Notarangelo FM, Guidetti P, Wu HQ, Lee J, Truong J, Andrews-Zwilling Y, Hsieh EW, et al: Kynurenine 3-monooxygenase inhibition in blood ameliorates neurodegeneration. Cell 145: 863-874, 2011.

19. Kubo H,Hoshi M, Mouri A, Tashita C, Yamamoto Y,Nabeshima T and Saito K: Absence of kynurenine 3-monooxygenase reduces mortality of acute viral myocarditis in mice. Immunol Lett 181: 94-100, 2017.

20. Mole DJ, Webster SP, Uings I, Zheng X, Binnie M, Wilson K, Hutchinson JP, Mirguet O, Walker A, Beaufils B, et al: Kynurenine-3-monooxygenase inhibition prevents multiple organ failure in rodent models of acute pancreatitis. Nat Med 22: 202-209, 2016.

21. Wang Y, Merchen TD, Fang X, Lassiter R, Ho CS, Jajosky R, Kleven D, Thompson T, Mohamed E, Yu M, et al: Regulation of indoleamine 2,3 dioxygenase and its role in a porcine model of acute kidney allograft rejection. J Investig Med 66: 1109-1117, 2018.

22. Terness P, Bauer TM, Röse L, Dufter C, Watzlik A, Simon H and Opelz G: Inhibition of allogeneic T cell proliferation by indoleamine 2,3-dioxygenase-expressing dendritic cells: Mediation of suppression by tryptophan metabolites. J Exp Med 196: 447-457, 2002.

23. Hoshi M, Kubo H, Ando T, Tashita C, Nakamoto K, Yamamoto Y, Tezuka $\mathrm{H}$ and Saito K: 3-Hydroxykynurenine regulates lipopolysaccharide-stimulated IL-6 production and protects against endotoxic shock in mice. Immunohorizons 5: 523-534, 2021.

24. Sabattini E, Bacci F, Sagramoso C and Pileri SA: WHO classification of tumours of haematopoietic and lymphoid tissues in 2008: An overview. Pathologica 102: 83-87, 2010.

25. Miller AA and Salewski E: Prospects for pirarubicin. Med Pediatr Oncol 22: 261-268, 1994.

26. Takagi T and Oguro M: (2"-R)-4'-o-tetrahydropyranyladriamycin, a new anthracycline derivative; its effectiveness in lymphoid malignancies. Cancer Chemother Pharmacol 20: 151-154, 1987.

27. Tsurumi H, Yamada T, Sawada M, Kasahara S, Kanemura N, Kojima Y, Fukuno K, Hara T, Saio M, Takahashi T, et al: Biweekly CHOP or THP-COP regimens in the treatment of newly diagnosed aggressive non-Hodgkin's lymphoma. A comparison of doxorubicin and pirarubicin: A randomized phase II study. J Cancer Res Clin Oncol 130: 107-113, 2004.

28. Tsurumi H, Hara T, Goto N, Kanemura N, Kasahara S, Sawada M, Yasuda I, Yamada T, Shimizu M, Takami T, et al: A phase II study of a THP-COP regimen for the treatment of elderly patients aged 70 years or older with diffuse large B-cell lymphoma. Hematol Oncol 25: 107-114, 2007.

29. International Non-Hodgkin's Lymphoma Prognostic Factors Project: A predictive model for aggressive non-Hodgkin's lymphoma. N Engl J Med 329: 987-994, 1993.

30. Sehn LH, Berry B, Chhanabhai M, Fitzgerald C, Gill K, Hoskins P, Klasa R, Savage KJ, Shenkier T, Sutherland J, et al: The revised International Prognostic Index (R-IPI) is a better predictor of outcome than the standard IPI for patients with diffuse large B-cell lymphoma treated with R-CHOP. Blood 109: 1857-1861, 2007.

31. Saito K, Quearry BJ, Saito M, Nowak TS Jr, Markey SP and Heyes MP: Kynurenine 3-hydroxylase in brain: Species activity differences and effect of gerbil cerebral ischemia. Arch Biochem Biophys 307: 104-109, 1993. 
32. Skouras C, Zheng X, Binnie M, Homer NZ, Murray TB, Robertson D, Briody L, Paterson F, Spence H, Derr L, et al: Increased levels of 3-hydroxykynurenine parallel disease severity in human acute pancreatitis. Sci Rep 6: 33951, 2016.

33. Hajsl M, Hlavackova A, Broulikova K, Sramek M, Maly M, Dyr JE and Suttnar J: Tryptophan metabolism, inflammation, and oxidative stress in patients with neurovascular disease. Metabolites 10: 208, 2020.

34. Carbone PP, Kaplan HS, Musshoff K, Smithers DW and Tubiana M: Report of the committee on Hodgkin's disease staging classification. Cancer Res 31: 1860-1861, 1971

35. Ikezoe T, Miyagi T, Kubota T, Taguchi T, Ohtsuki Y, Miyake K, Inokuchi K, Nomura T, Koeffler HP and Miyoshi I: Inactivation of the DCC tumor suppressor gene in a B-cell lymphoma cell line with the alteration of chromosome 18. Am J Hematol 50: 124-132, 1995

36. Taira T, Nagasaki A, Tomoyose T, Miyagi J, Kakazu N, Makino S, Shinjyo T, Taira N, Masuda M and Takasu N: Establishment of a human herpes virus-8-negative malignant effusion lymphoma cell line (STR-428) carrying concurrent translocations of BCL2 and c-MYC genes. Leuk Res 31: 1285-1292, 2007.

37. Hans CP, Weisenburger DD, Greiner TC, Gascoyne RD, Delabie J, Ott G, Müller-Hermelink HK, Campo E, Braziel RM, Jaffe ES, et al: Confirmation of the molecular classification of diffuse large B-cell lymphoma by immunohistochemistry using a tissue microarray. Blood 103: 275-282, 2004.

38. Hoshi M, Saito K, Hara A, Taguchi A, Ohtaki H, Tanaka R, Fujigaki H, Osawa Y, Takemura M, Matsunami H, et al: The absence of IDO upregulates type I IFN production, resulting in suppression of viral replication in the retrovirus-infected mouse. J Immunol 185: 3305-3312, 2010.

39. Garten A, Schuster S, Penke M, Gorski T, de Giorgis T and Kiess W: Physiological and pathophysiological roles of NAMPT and NAD metabolism. Nat Rev Endocrinol 11: 535-546, 2015.

40. Kaper T, Looger LL, Takanaga H, Platten M, Steinman L and Frommer WB: Nanosensor detection of an immunoregulatory tryptophan influx/kynurenine efflux cycle. PLoS Biol 5: e257, 2007.

41. Ninomiya S, Hara T, Tsurumi H, Hoshi M, Kanemura N, Goto N, Kasahara S, Shimizu M, Ito H, Saito K, et al: Indoleamine 2,3-dioxygenase in tumor tissue indicates prognosis in patients with diffuse large B-cell lymphoma treated with R-CHOP. Ann Hematol 90: 409-416, 2011.

42. Vazquez S, Garner B, Sheil MM and Truscott RJ: Characterisation of the major autoxidation products of 3-hydroxykynurenine under physiological conditions. Free Radic Res 32: 11-23, 2000.
43. Chiarugi A, Dölle C, Felici R and Ziegler M: The NAD metabolome - a key determinant of cancer cell biology. Nat Rev Cancer 12: 741-752, 2012.

44. Chiche J, Pommier S, Beneteau M, Mondragón L, Meynet O, Zunino B, Mouchotte A, Verhoeyen E, Guyot M, Pagès G, et al: GAPDH enhances the aggressiveness and the vascularization of non-Hodgkin's B lymphomas via NF- $\mathrm{B}$-dependent induction of HIF-1 $\alpha$. Leukemia 29: 1163-1176, 2015.

45. Chowdhury S, Sripathy S, Webster A, Park A, Lao U, Hsu JH, Loe T, Bedalov A and Simon JA: Discovery of selective SIRT2 inhibitors as therapeutic agents in B-cell lymphoma and other malignancies. Molecules 25: 455, 2020.

46. Braidy N, Grant R, Brew BJ, Adams S, Jayasena T and Guillemin GJ: Effects of kynurenine pathway metabolites on intracellular NAD synthesis and cell death in human primary astrocytes and neurons. Int J Tryptophan Res 2: 61-69, 2009.

47. Pittelli M, Formentini L, Faraco G, Lapucci A, Rapizzi E, Cialdai F, Romano G, Moneti G, Moroni F and Chiarugi A: Inhibition of nicotinamide phosphoribosyltransferase: Cellular bioenergetics reveals a mitochondrial insensitive NAD pool. J Biol Chem 285: 34106-34114, 2010.

48. KristeleitR, Davidenko I, Shirinkin V,El-Khouly F, Bondarenko I, Goodheart MJ, Gorbunova V, Penning CA, Shi JG, Liu X, et al: A randomised, open-label, phase 2 study of the IDO1 inhibitor epacadostat (INCB024360) versus tamoxifen as therapy for biochemically recurrent (CA-125 relapse)-only epithelial ovarian cancer, primary peritoneal carcinoma, or fallopian tube cancer. Gynecol Oncol 146: 484-490, 2017.

49. Beatty GL, O'Dwyer PJ, Clark J, Shi JG, Bowman KJ, Scherle PA, Newton RC, Schaub R, Maleski J, Leopold L, et al: First-in-human phase I study of the oral inhibitor of indoleamine 2,3-dioxygenase-1 epacadostat (INCB024360) in patients with advanced solid malignancies. Clin Cancer Res 23: 3269-3276, 2017.

50. Alizadeh AA, Eisen MB, Davis RE, Ma C, Lossos IS, Rosenwald A, Boldrick JC, Sabet H, Tran T, Yu X, et al: Distinct types of diffuse large B-cell lymphoma identified by gene expression profiling. Nature 403: 503-511, 2000.

This work is licensed under a Creative Commons Attribution-NonCommercial-NoDerivatives 4.0 International (CC BY-NC-ND 4.0) License. 